\title{
KVALITETA BLISKIH ODNOSA KOD VLASNIKA PASA I ASPEKTI PRIVRŽENOSTI KUĆNOM LJUBIMCU
}

\author{
Jelena Ombla \\ Odjel za psihologiju, Sveučilište u Zadru \\ Obala kralja Petra Krešimira IV br. 2, 23000 Zadar \\ jlevac@unizd.hr \\ Marina Vidaković \\ Odjel za psihologiju, Sveučilište u Zadru \\ Obala kralja Petra Krešimira IV br. 2, 23000 Zadar \\ mjurkin@unizd.hr
}

\begin{abstract}
Sažetak
Odnos između vlasnika i njihovih kućnih ljubimaca nema eksplicitno definiranu svrhu, ipak čini se da poprima obilježja obostranog afektivnog odnosa. Ovo je posebice istaknuto kada je riječ o psima kao kućnim ljubimcima, koji osim što su najpopularnija vrsta ljubimaca, ujedno su i vrsta za koju se čovjek snažno emocionalno veže. Istraživanja pokazuju kako u nekim slučajevima kućni ljubimci zamjenjuju manjak veza privrženosti s ljudima, dok u drugima proširuju raspon veza i socijalnih kontakata koji doprinose općem životnom zadovoljstvu te pružaju osjećaj ugode i potpore $\mathrm{u}$ težim trenucima.

Cilj ovog istraživanja bio je pokušati utvrditi razlikuju li se dvije skupine vlasnika pasa u nekim odrednicama kvalitete bliskih interpersonalnih odnosa uzevši pritom u obzir aspekte privrženosti koje ostvaruju u odnosu sa svojim ljubimcem.

Rezultati potvrđuju očekivanja; uzorak vlasnika pasa do kojeg se došlo tehnikom tzv. snježne grude realizira kvalitetnije bliske interpersonalne odnose i iskazuje veće životno zadovoljstvo, dok tzv. samoregrutirani uzorak vlasnika pasa slabije funkcionira u odnosima sa značajnim drugima, a uz to su i manje zadovoljni životom. Nadalje, skupina vlasnika pasa koja je lošija na interpersonalnom planu, privrženija je svom ljubimcu. Njihova motivacija za socijalnim kontaktom istaknuta je u potrebi za pažnjom i samouzdizanjem koje proizlazi iz te pažnje, što upućuje na moguće faktore unutar ličnosti koji bi mogli biti važni za interpersonalno funkcioniranje.
\end{abstract}

Ključne riječi: privrženost, usamljenost, interpersonalni odnosi, kućni ljubimci 


\section{UVOD}

Privrženost čovjeka kućnom ljubimcu, u znanstvenom se okružju promatra primarno u kontekstu provjere tzv. pozitivnog efekta ljubimca. Pitanja mentalnog zdravlja vlasnika kućnih ljubimaca vjerojatno su najviše zanimala psihologe čija je znanstvena znatiželja bila usmjerena ka što potpunijem razumijevanju odnosa veze čovjeka i životinje. Čini se da do sada veći dio rezultata daje potporu upravo hipotezi o pozitivnom efektu posjedovanja kućnih ljubimaca na zdravlje, međutim ima i kontradiktornih nalaza. Budući da je ovo područje znanstvenog djelovanja još relativno mlado i nedovoljno istraženo, takvi se nalazi dijelom mogu pripisati metodologiji; u određenim istraživanjima nije bila kontrolirana kvaliteta privrženosti, a postoji i jasan zahtjev za razvojem većeg broja valjanih mjera. Međutim, jasna je i potreba za ispitivanjem različitih aspekata odnosa čovjeka i životinje, izvan same privrženosti.

Postojanje višestrukih teorijskih i empirijskih konceptualizacija privrženosti otežava istraživanja u ovom području (Mikulincer i Shaver, 2007), što je dodatno naglašeno kada je riječ o propitkivanju karakteristika odnosa vlasnik-kućni ljubimac. U ovom su istraživanju zastupljeni oni koncepti privrženosti koji se smatraju teorijski najrelevantnijim: funkcije privrženosti (separacijska anksioznost, sigurno utočište) i dimenzije privrženosti (anksioznost, izbjegavanje) koje su mjerene kod četiri tipa bliskih odnosa (partner, najbolji prijatelj, član obitelji i kućni ljubimac), te stupanj afektivne vezanosti za ljubimca kao mjera emocionalne bliskosti u odnosu s psom. Odnos s kućnim ljubimcem pokušao se interpretirati u kontekstu drugih bliskih (privrženih) odnosa. Pritom se relevantnom promatrala uloga percepcije socijalne okoline u smislu usamljenosti u bliskim odnosima.

Regrutaciji sudionika u ovom istraživanju pristupilo se principom ,snježne grude“ te oglašavanjem informacije o provođenju istraživanja na relevantnim web stranicama, što je navelo dio sudionika da sami kontaktiraju glavnog istraživača izražavajući pritom svoju želju za sudjelovanjem. Ovom tehnikom pribavljanja uzorka, koja se sastojala u samoinicijativnoj reakciji vlasnika pasa na "oglas", nastojao se provjeriti Kurdekov (2009) zaključak o samoregrutiranom uzorku kao istraživački pristranom. Uz pretpostavku da će samoregrutirani uzorak vlasnika pasa iskazati izraženiju privrženost svom ljubimcu, odnosno da će se u tom razlikovati od uzorka vlasnika pasa kojima se pristupilo na klasičan način, krenulo se u provjeru razlika u temeljnim varijablama interpersonalnog funkcioniranja u bliskim odnosima između ove dvije skupine sudionika, što je bio osnovni istraživački cilj.

Dodatne varijable koje su uključene u istraživanje odnosile su se na neke osobne značajke (generativnost, afilijativna motivacija i stavovi prema kućnim ljubimcima) koje se u empirijskoj literaturi promatraju kao antecedente, te procjenu dobrobitiživotno zadovoljstvo koja se promatra kao ishodna varijabla odnosa vlasnik-kućni ljubimac. 
U našoj zemlji tematika odnosa koji se formira između ljudi i njihovih kućnih ljubimaca predstavlja relativno neistraženo područje, dok se u svijetu istraživanja bave ovom tematikom posljednjih tridesetak godina. Stoga se smatralo relevantnim pokušati doći do nekih inicijalnih zaključaka o odnosu koji čovjek uspostavlja sa svojim kućnim ljubimcima, i na uzorku hrvatskih vlasnika pasa.

\section{METODA}

Istraživanje je obuhvatilo ukupno 286 vlasnika kućnih ljubimaca - pasa (prosječna dob uzorka je 34 godine). U istraživanju su sudjelovali samo vlasnici pasa budući da se pokazalo kako postoje značajne razlike u stupnju afektivne vezanosti za ljubimca s obzirom na vrstu životinje, dok je isti općenito najsnažnije izražen kada je riječ o psima (npr. Siegel, 1990; Johnson, Garrity i Stallones, 1992). Uzorak čine vlasnici koji su primarno odgovorni za skrb o ljubimcu i čiji ljubimci borave $\mathrm{u}$ istom životnom prostoru s vlasnicima. Naime, u literaturi se navodi kako se oni vlasnici kućnih ljubimaca koji skrbe o ljubimcu razlikuju u stavovima prema ljubimcima, percepciji vlastitog ljubimca i ponašanjima prema ljubimcu u odnosu na one vlasnike koji sebe ne identificiraju kao skrbnike (Carlisle-Frank i Frank, 2006). Također, stupanj uključenosti u aktivnosti skrbi za psa pozitivno je povezan s oznakama privrženosti ljubimcu (Kurdek, 2008; Ombla i Penezić, 2010), dok su se vlasnici kućnih pasa pokazali privrženijima svojim ljubimcima u odnosu na vlasnike dvorišnih pasa (Shore, Riley i Douglas, 2006). Činjenica da su u ovo istraživanje bili uključeni samo primarni vlasnici pasa (dakle jedna osoba unutar kućanstva koja se prema nizu kriterija identificirala kao primarni skrbnik psa) vjerojatno je povezana s podatkom da uzorak mahom čine žene (otprilike $82 \%$ ). Naime, rodna raspodjela rada u socijalnoj okolini i dalje odrasloj ženi pridaje ulogu primarnog skrbnika u okviru domene obitelji, dakle nekog tko preuzima glavninu brige o potrebama članova obitelji na svakodnevnoj razini, poglavito u još prilično tradicionalnom društvu kakvo prevladava u našoj zemlji (Jugović, 2004).

Ukupan uzorak činile su dvije podskupine vlasnika pasa: njih 219 pristupilo je popunjavanju upitnika nakon što ih je osobno kontaktirao glavni istraživač (ili suradnici) vodeći se informacijom da se radi o vlasnicima pasa, dok je manja skupina, njih 67, osobno kontaktirala istraživača te zatražila upitnik nakon što su vidjeli informaciju o provođenju istraživanja oglašenu na internetu. Budući da je oglas bio postavljen na Facebook stranice udruga za zaštitu i udomljavanje napuštenih i nezbrinutih životinja te na stranice grupa koje okupljaju vlasnike kućnih ljubimaca, u startu je bila dostupna još jedna opća informacija o karakteristikama manje skupine, a to je da se radi o onim vlasnicima pasa koji su na neki način dodatno angažirani u aktivnostima skrbi za životinje, izvan onih vezanih uz brigu o vlastitom ljubimcu. Ovako formirane dvije podskupine vlasnika pasa nisu se statistički značajno razlikovale u osnovnim sociodemografskim varijablama (v. Tablicu 1) niti u osnovnim 
Tablica 1. Sociodemografski sastav dviju skupina sudionika

\begin{tabular}{|c|c|c|c|c|c|c|}
\hline Varijabla & & $n 1=219$ & $n 2=67$ & $\chi^{2}$ & $d f$ & $p$ \\
\hline \multirow{2}{*}{ Spol } & $\mathrm{M}$ & 40 & 11 & 0,119 & 1 & $>0,05$ \\
\hline & $\check{Z}$ & 179 & 56 & & & \\
\hline \multirow{4}{*}{$\begin{array}{l}\text { Školska } \\
\text { sprema }\end{array}$} & osnovna & 1 & 0 & 0,680 & 3 & $>0,05$ \\
\hline & srednja & 98 & 33 & & & \\
\hline & viša & 33 & 10 & & & \\
\hline & visoka & 87 & 24 & & & \\
\hline \multirow{5}{*}{$\begin{array}{l}\text { Materijalno } \\
\text { stanje }\end{array}$} & znatno lošije od prosj. & 3 & 0 & 3,752 & 4 & $>0,05$ \\
\hline & lošije od prosj. & 11 & 6 & & & \\
\hline & prosječno & 152 & 49 & & & \\
\hline & bolje od prosj. & 49 & 8 & & & \\
\hline & znatno bolje od prosj. & 4 & 4 & & & \\
\hline \multirow{5}{*}{$\begin{array}{l}\text { Romantični } \\
\text { status }\end{array}$} & samaštvo & 44 & 17 & 1,360 & 4 & $>0,05$ \\
\hline & veza & 62 & 16 & & & \\
\hline & izvanbr. zajednica & 20 & 9 & & & \\
\hline & brak & 91 & 25 & & & \\
\hline & udovištvo & 2 & 0 & & & \\
\hline \multirow{2}{*}{ Roditeljstvo } & da & 87 & 25 & 0,166 & 1 & $>0,05$ \\
\hline & ne & 130 & 42 & & & \\
\hline \multirow[b]{2}{*}{ Dob } & & $n 1=219$ & $n 2=67$ & $t$ & $d f$ & $p$ \\
\hline & & 34,18 & 34,64 & $-0,291$ & 284 & 0,771 \\
\hline
\end{tabular}

Napomena: pri izračunu značajnosti razlika u vrijednostima kategorijalnih varijabli korišten je $\chi^{2}$ test za nezavisne uzorke, dok je za testiranje značajnosti razlika u dobi proveden $t$-test za nezavisne uzroke

Tablica 2. Skrb za ljubimca, vrijeme posjedovanja ljubimca, broj ljubimaca kod dvije skupine sudionika (t-testovi za nezavisne uzorke)

\begin{tabular}{lrrrrrc}
\hline Varijabla & $N$ & $M$ & $S d$ & $t$ & $d f$ & $p$ \\
\hline Skrb za ljubimca (prosječni rezultat & 219 & 47,54 & 4,01 & \multirow{2}{*}{0,142} & 284 & $>0,05$ \\
na Skali skrbi za ljubimca) & 67 & 47,46 & 3,68 & & & \\
\hline Procjena opterećenosti skrbljenjem & 219 & 2,47 & 1,17 & \multirow{2}{*}{ (1,386 } & 284 & $>0,05$ \\
za ljubimca (1 čestica) & 67 & 2,71 & 1,13 & & & \\
\hline Vrijeme posjedovanja psa & 219 & 4,44 & 3,51 & \multirow{2}{*}{2,036} & 284 & $<\mathbf{0 , 0 5}$ \\
& 67 & 5,47 & 4,08 & & & \\
Ukupan broj ljubimaca & 219 & 1,89 & 1,81 & $-1,037$ & 284 & $>0,05$ \\
\hline Ukupan broj pasa & 67 & 2,16 & 1,86 & & & \\
& 219 & 1,13 & 0,83 & \multirow{2}{*}{0,910} & 284 & $>0,05$ \\
\hline
\end{tabular}


aspektima skrbi za ljubimca te broju ljubimaca, dok je kod manjeg uzorka vlasnika pasa utvrđeno nešto duže vrijeme posjedovanja psa (v. Tablicu 2).

\section{INSTRUMENTI}

U istraživanju je primijenjen upitnik koji se sastojao od uvodnog dijela strukturiranog upitnika osobnih podataka, te baterije skala i upitnika.

Mjerni instrumenti zastupljeni u primijenjenom upitniku bili su sljedeći:

1. Upitnik karakteristika i funkcija privrženosti (Ombla, 2014)

2. Adaptirana Lexington skala privrženosti kućnim ljubimcima (Levačić, 2009)

3. Modificirani Brennanov Inventar iskustava u bliskim vezama (Kamenov i Jelić, 2003)

4. Skala socijalne i emocionalne usamljenosti (Ćubela Adorić, 2004)

5. Skala životnog zadovoljstva (Diener, Emmons, Larsen i Griffin, 1985)

6.Skala stavova prema kućnim ljubimcima (Ombla i Penezić, 2010)

7.Adaptirana Loyola skala generativnosti(Lacković-Grgin, 2004)

8. Skala afilijativne motivacije (Lacković-Grgin, 2002)

Upitnik karakteristika i funkcija privrženosti (Ombla, 2014) predstavlja mjeru karakteristika i funkcija privrženosti u trenutačnim odnosima s bliskim drugim osobama. Sudionici zasebno procjenjuju odnos s članom obitelji (pri čemu se trebaju odlučiti za majku, oca, sestru ili brata), partnerom, najboljim prijateljem i svojim kućnim ljubimcem (psom). Rezultat na skali Separacijska anksioznost upućuje na potrebu za blizinom procjenjivane figure i na osjećaje uznemirenosti i tjeskobe pri njenoj odsutnosti, dok rezultat na skali Sigurno utočište upućuje na osjećaj sigurnosti, utjehe i potpore koji proizlazi iz društva procjenjivane figure. Prema Ombla (2014), pouzdanosti skala Upitnika karakteristika i funkcija privrženosti dosta su visoke te se za subskalu Separacijska anksioznost kreću od $\alpha=0,88$ do $\alpha=0,84$, ovisno o procjenjivanom odnosu. Pouzdanosti skale Sigurno utočište kreću se od $\alpha$ $=0,94$ do $\alpha=0,91$, ovisno o procjenjivanom odnosu. Opravdano je računati i jedan ukupan rezultat.

Adaptirana Lexington skala privrženosti kućnim ljubimcima (Levačić, 2009) sadrži opise aktivnosti, stajališta i osjećaja vlasnika u odnosu s njegovim ljubimcem koji sadržajno pokrivaju afektivnu dimenziju odnosa. Skala ima jednofaktorsku strukturu, te visoku pouzdanost od 0,95 (Levačić, 2009). Odgovori na čestice ove skale izražavaju jednu generalnu afektivnu orijentaciju prema životinji, odnosno kućnom ljubimcu koja se može nazvati "općom privrženošću".

Modificirani Brennanov Inventar iskustava u bliskim vezama (Kamenov i Jelić, 2003) ispituje privrženost unutar tri domene bliskih odnosa: Upitnik privrženosti prema članovima obitelji, Upitnik privrženosti prema ljubavnim partnerima i Upit- 
nik privrženosti prema prijateljima. Sve tri verzije skale imaju dvofaktorsku latentnu strukturu. Rezultat na subskali Anksioznost upućuje na osjećaje brige vezane uz kontekst bliskosti u odnosu, dok rezultat na subskali Izbjegavanje upućuje na odbijanje intimnosti. Koeficijenti pouzdanosti kreću od $\alpha=0,65$ do $\alpha=0,90$, ovisno o procjenjivanoj domeni (obiteljska, ljubavna, prijateljska).

Skala socijalne i emocionalne usamljenosti (Ćubela Adorić, 2004) sastoji se od tri subskale koje ispituju usamljenost unutar prijateljskih odnosa, odnosa s obitelji i ljubavnih veza. Usamljenost u prijateljskim odnosima odražava konstrukt socijalne usamljenosti (nedovoljna socijalna integracija), dok usamljenost u obitelji i ljubavi odražava konstrukt emocionalne usamljenosti (nepostojanje ili gubitak odnosa privrženosti). Koeficijenti pouzdanosti pojedinih subskala kreću se od 0,85 za subskalu Usamljenost u obitelji, 0,89 za subskalu Socijalna usamljenost i 0,91 za Usamljenost u ljubavi.

Skala životnog zadovoljstva (Diener i sur., 1985) daje podatak o općem zadovoljstvu životom. Diener i suradnici (1985) izvještavaju o visokoj pouzdanosti tipa unutrašnje konzistencije $(\alpha=0,87)$.

Skala stavova prema kućnim ljubimcima (Ombla i Penezić, 2010) daje podatak o općem stavu prema držanju kućnih ljubimaca. Skala je jednofaktorske strukture i visoke ukupne pouzdanosti $\alpha=0,95$.

Adaptirana Loyola skala generativnosti (Lacković-Grgin, 2004) mjeri generativnu brigu, koja je u modelu McAdamsa i de St Aubina (1992) ključna komponenta generativnosti. Rezultat upućuje na nastojanja da se pruži doprinos zajednici i društvu, nastojanja da se bude kreativan i produktivan, itd. Koeficijent pouzdanosti iznosi 0,83 .

Skala afilijativne motivacije (Lacković-Grgin, 2002) predstavlja mjeru motivacije za socijalnim kontaktom. Ima četiri subskale čiji rezultati upućuju na različite dimenzije afilijativne motivacije (emocionalna podrška, socijalna usporedba, pozitivna stimulacija i pažnja). Pouzdanost cijele skale iznosi $\alpha=0,87$, odnosno po subskalama kreće se od 0,85 do 0,95.

\section{REZULTATI}

U Tablici 3 prikazani su rezultati testiranja značajnosti razlika u varijablama privrženosti kod dvije skupine sudionika (t-test za nezavisne uzorke). Veća skupina sudionika $(n 1=219)$ percipira značajno više sigurnosti, utjehe i podrške u odnosu s članom obitelji, partnerom i prijateljem (Sigurno utočište) te izražava značajno manje anksioznosti i izbjegavanja glede obiteljskih, partnerskih i prijateljskih odnosa. S druge strane, kod manje skupine sudionika $(n 2=67)$ naglašen je značajno izraženiji doživljaj sigurnog utočišta te separacijske anksioznosti u odnosu s kućnim 
ljubimcem. Manja skupina vlasnika pasa doživljava i značajno više usamljenosti u obiteljskoj, partnerskoj i socijalnoj interpersonalnoj domeni te izražava značajno nižu razinu općeg zadovoljstva životom kada se usporedi s većom skupinom. Kod iste skupine vlasnika pasa značajno je izraženija dimenzija Pažnje kao aspekta afilijativne motivacije (Tablica 4).

Tablica 3. Testiranje značajnosti razlika u varijablama privrženosti između dvije skupine sudionika (t-test za nezavisne uzorke)

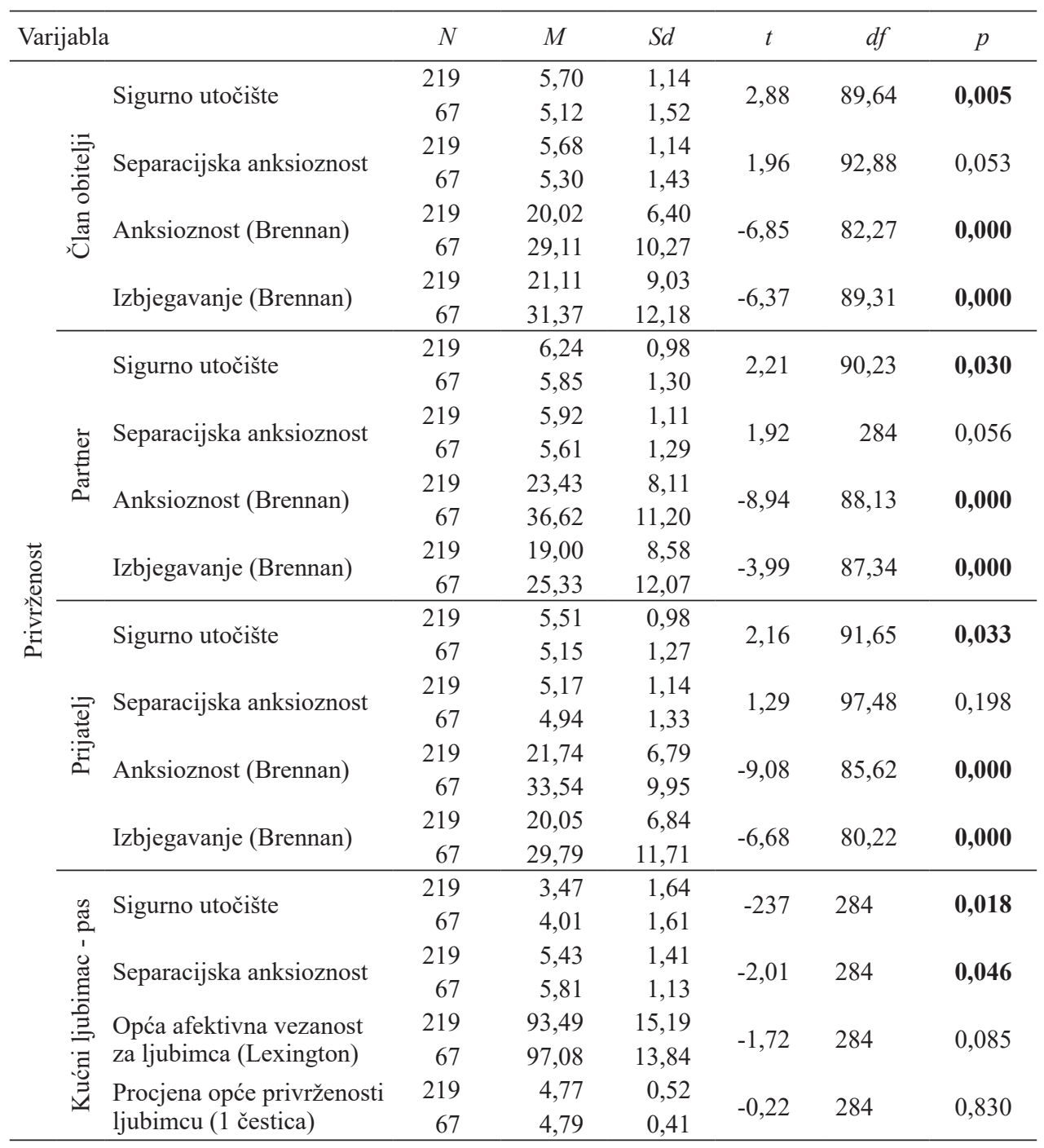


Tablica 4. Testiranje značajnosti razlika u varijablama usamljenosti, životnog zadovoljstva, generativnosti, stavu prema držanju kućnih ljubimaca te afilijativne motivacije između dvije skupine sudionika (t-test za nezavisne uzorke)

\begin{tabular}{|c|c|c|c|c|c|c|c|}
\hline Varijabla & & $N$ & $M$ & $S d$ & $t$ & $d f$ & $p$ \\
\hline \multirow{6}{*}{ Usamljenost } & \multirow{2}{*}{ Socijalna usamljenost } & 219 & 24,1 & 7,66 & \multirow{2}{*}{$-5,02$} & \multirow{2}{*}{79,06} & \multirow{2}{*}{0,000} \\
\hline & & 67 & 32,8 & 13,67 & & & \\
\hline & \multirow{2}{*}{ Usamljenost u ljubavi } & 219 & 29,9 & 16,08 & \multirow{2}{*}{$-3,22$} & \multirow{2}{*}{91,66} & \multirow{2}{*}{0,000} \\
\hline & & 67 & 38,8 & 20,71 & & & \\
\hline & \multirow{2}{*}{ Usamljenost u obitelji } & 219 & 16,1 & 9,03 & \multirow{2}{*}{$-5,47$} & \multirow{2}{*}{79,79} & \multirow{2}{*}{$\mathbf{0 , 0 0 0}$} \\
\hline & & 67 & 26,1 & 12,18 & & & \\
\hline \multirow{2}{*}{\multicolumn{2}{|c|}{ Životno zadovoljstvo }} & 219 & 3,61 & 0,74 & \multirow{2}{*}{4,48} & \multirow{2}{*}{284} & \multirow{2}{*}{0,000} \\
\hline & & 67 & 3,13 & 0,79 & & & \\
\hline \multirow{2}{*}{\multicolumn{2}{|c|}{ Generativnost }} & 219 & 3,5 & 0,58 & \multirow{2}{*}{$-1,14$} & \multirow{2}{*}{284} & \multirow{2}{*}{0,257} \\
\hline & & 67 & 3,6 & 0,52 & & & \\
\hline \multirow{2}{*}{\multicolumn{2}{|c|}{ Stav prema kućnim ljubimcima }} & 219 & 80,5 & 5,7 & \multirow{2}{*}{$-0,859$} & \multirow{2}{*}{284} & \multirow{2}{*}{0,391} \\
\hline & & 67 & 81,2 & 5,51 & & & \\
\hline \multirow{8}{*}{$\begin{array}{l}\text { Afilijativna } \\
\text { motivacija }\end{array}$} & \multirow{2}{*}{ Emoc. podrška } & 219 & 24,1 & 5,22 & \multirow{2}{*}{0,331} & \multirow{2}{*}{284} & \multirow{2}{*}{0,741} \\
\hline & & 67 & 23,8 & 5,09 & & & \\
\hline & \multirow{2}{*}{ Soc. usporedba } & 219 & 12,3 & 2,77 & \multirow{2}{*}{1,1} & \multirow{2}{*}{284} & \multirow{2}{*}{0,282} \\
\hline & & 67 & 11,9 & 2,91 & & & \\
\hline & \multirow{2}{*}{ Poz. stimulacija } & 219 & 23,4 & 4,6 & 12 & 28 & 0217 \\
\hline & & 67 & 22,6 & 5,37 & 1,24 & 284 & 0,217 \\
\hline & Paร̌nia & 219 & 12,1 & 4,21 & -289 & 284 & 0,004 \\
\hline & raznja & 67 & 13,9 & 4,19 & $-2,09$ & 204 & \\
\hline
\end{tabular}

Napomena (Tablica 3, Tablica 4): Prilikom provođenja t- testova u slučajevima određenih varijabli preduvjetna pretpostavka o homogenosti varijanci dvaju uzoraka nije bila zadovoljena te je stoga napravljena korekcija u obliku Leveneova testa, koji u tom slučaju daje korigiranu vrijednost stupnjeva slobode kao i vrijednosti t-statistika.

\section{RASPRAVA}

Upravo je kontekst razvoja afektivnog odnosa prema ljubimcu tema ovog istraživanja u kojem se krenulo primarno od provjere nekih obilježja kvalitete bliskih odnosa kod vlasnika pasa. U startu se pretpostavilo kako će dvije ciljane tehnike regrutacije sudionika rezultirati vlasnicima pasa koji će se razlikovati u kvaliteti afektivnog odnosa koji imaju sa svojim ljubimcem. Upravo je za interpersonalni kontekst, u okviru kojeg se razvija odnos s ljubimcem, pretpostavljeno da je faktor relevantan za realizaciju privrženosti u odnosu s ljubimcem. Kurdek (2008) navodi kako je moguće da ljudi u bliskom odnosu s ljubimcem pronalaze supstitut za nezadovoljavajuće odnose s bliskim drugima, ali i da oni koji se snažno vežu za ljubimca time zapravo generaliziraju iskustvo pozitivnih odnosa s drugima.

Istraživanje je obuhvatilo dvije različite metode regrutacije sudionika temeljem čega su formirana dva uzorka sudionika. Dvije skupine vlasnika pasa su usporedi- 
vog sociodemografskog sastava, dok je prosječno vrijeme posjedovanja ljubimca nešto duže kod manjeg uzorka. Ispitivanje razlika u procjenama na temeljnim varijablama ovog istraživanja, varijablama privrženosti, rezultiralo je statistički značajnim razlikama u većini slučajeva testiranih varijabli. Ono što se na prvi pogled posve jasno primjećuje, jesu zastupljenije oznake sigurnosti privrženosti u odnosima u okviru tri obuhvaćene interpersonalne domene (obitelj, romantični odnosi, prijatelji) kod veće skupine vlasnika pasa. Naime, pripadnici veće skupine, u odnosu na manju skupinu vlasnika pasa, percipiraju značajno viši stupanj realizacije privrženog ponašanja u trima interpersonalnim domenama, odnosno skloniji su u trenucima stresa i nesigurnosti potražiti utjehu i povratiti osjećaj stabilnosti u blizini obitelji, partnera i najboljeg prijatelja. Veća skupina vlasnika pasa izražava i značajno manje anksioznosti i izbjegavanja u trima relevantnim domenama odnosa kada se usporedi s manjom skupinom vlasnika pasa. Drugim riječima, sigurniji su u svoje bliske odnose, imaju više povjerenja, spremniji su emocionalno se vezati i primjereniji su u svojim zahtjevima. Zaključak o boljem funkcioniranju veće skupine vlasnika pasa u smislu realizacije prisnijih odnosa sa značajnim drugima, nadalje podupiru rezultati testiranja razlika u varijablama usamljenosti i životnom zadovoljstvu. Pripadnici veće skupine vlasnika pasa doživljavaju značajno manje usamljenosti u obiteljskoj, ljubavnoj i socijalnoj domeni odnosâ, te izražavaju značajno više opće zadovoljstvo životom kada se usporede s manjom skupinom vlasnika pasa. Ovi se rezultati mogu povezati s općim modelom predikcije usamljenosti Larosea, Guaya i Boivina (2002), u kojem se kao osobna dispozicija relevantna za doživljaj usamljenosti, promatra upravo privrženost. Ovi su autori, između ostalog, na uzorku osoba mlađe odrasle dobi utvrdili kako upravo nesigurna privrženost uz nisku percipiranu emocionalnu podršku značajno pridonosi usamljenosti. Drugim riječima, privrženost se promatra kao individualna osobina pojedinca koja, s obzirom na određeni obrazac misli, osjećaja i ponašanja koji se vezuje uz percepciju značajnih drugih i sebe u odnosima s tim značajnim drugima, uvjetuje stupanj ostvarene bliskosti u odnosima, a time i trenutačan (na neki način i recipročan) doživljaj usamljenosti u odnosima. Shaver i Mikulincer (2010) navode kako radni modeli privrženosti mogu pospješiti, ali i omesti razvoj odnosâ. Tako sigurno privrženi imaju pozitivna očekivanja i stavove prema okolini, što ih potiče na predanost, imaju više povjerenja u partnere u odnosima te spremnije daju i primaju izraze podrške. S druge strane, nesigurno privrženi imaju negativna očekivanja od svoje okoline, što ih čini manje osjetlivivima pri davanju i primanju podrške, u smislu da odbijaju ili posve neresponzivno pretjeruju. Manja skupina vlasnika pasa, koja osim što iskazuje veću nesigurnost privrženosti u bliskim odnosima te doživljava značajno višu usamljenost i niže zadovoljstvo životom, s druge strane daje značajno više procjene na varijablama koje indiciraju realizaciju privrženog ponašanja u odnosu s ljubimcem (funkcije privrženosti) kada se usporedi s većim uzorkom. Dakle, realiziraju nesigurnije obrasce privrženosti u bliskim odnosima, uz to su usamljeniji i manje zadovoljni životom, ali su u predaniji svom ljubimcu, smatraju da im on 
pruža potrebnu utjehu u stresnim trenucima, teže im je prihvatiti razdvojenost od ljubimca. Ovo daje osobitu notu zanimljivosti kontekstu usporedbe dvaju uzoraka vlasnika pasa koji su sudjelovali u ovom istraživanju. Kurdek (2009) komentira neke specifičnosti dobivenih rezultata s obzirom na ,internetski“ regrutiran uzorak sudionika svoje studije. Naime, navodeći najznačajniji rezultat svoje studije prema kojem ljudi preferiraju psa pred ostalim bliskim figurama kada je riječ o doživljaju sigurnog utočišta (jedino je za partnera dobivena viša procjena), pojašnjava da se radi o skupini koja izražava i visoku afektivnu vezanost za ljubimca (negativno asimetrične distribucije rezultata). Autor nadalje pretpostavlja kako je kod uzoraka koji doista svojevoljno sudjeluju u istraživanjima (i njegov je uzorak reagirao na oglas o provođenju istraživanja te su sami pristupili internet adresi na kojoj se nalazio upitnik) moguće da se radi o skupinama pojedinaca koji su u startu pristrani prema temeljnom istraživačkom pitanju. Nadalje, zaključuje kako ti "samoregrutirani" uzorci, naročito kada je riječ o vlasnicima ljubimaca, zadovoljavaju optimalne uvjete kada je riječ o ispitivanju odnosa s ljubimcem, budući da se radi o skupinama doista posvećenih vlasnika ljubimaca.

Rezultati dobiveni u ovom istraživanju nadalje podupiru obje hipoteze koje su pokušale opisati vlasnike kućnih ljubimaca u interpersonalnom smislu (Kurdek, 2008). Opis većeg uzorka vlasnika pasa (sigurniji obrazac privrženosti prema bliskim osobama, manja usamljenost, veće životno zadovoljstvo) išao bi tako u prilog hipotezi o vlasnicima pasa kao osobama kojima je odnos s ljubimcem ishod generalizacije pozitivnih iskustava u bliskim odnosima sa značajnim drugima. Opis manje skupine vlasnika pasa (nesigurniji obrazac privrženosti prema bliskim osobama, veća usamljenost, manje životno zadovoljstvo) ide u prilog pretpostavci o vlasnicima ljubimaca kao osobama koje u odnosu s ljubimcem pronalaze supstitut za nerealizirane odnose s bliskim osobama. Činjenica da ti isti vlasnici ljubimaca ujedno ostvaruju i viši stupanj privrženosti u odnosu s ljubimcem upućuje na mogućnost da je upravo kvaliteta bliskih interpersonalnih odnosa faktor koji determinira privrženost $\mathrm{u}$ odnosu s ljubimcem. Pod kvalitetom bliskih odnosa, u ovom istraživanju, podrazumijevaju se individualne odrednice realizacije privrženosti u bliskim odnosima (anksioznost i izbjegavanje) nasuprot usamljenosti u bliskim odnosima kao stanju koje je determinirano tim odrednicama (Larose i sur., 2002). Detaljnija analiza rezultata koja bi ponudila provjeru gore spomenute pretpostavke nije moguća zbog brojčano malog uzorka vlasnika ljubimaca koji su se dobrovoljno javili za sudjelovanje u istraživanju. Međutim, već i indicije koje proizlaze iz ovdje prikazanih rezultata stvaraju dobru podlogu i usmjerenje za buduća istraživanja u ovom području. Zanimljivo je i da se dva uzorka vlasnika pasa zastupljena u ovom istraživanju ne razlikuju u stavovima prema kućnim ljubimcima niti u generativnosti, ali razlike postoje u dimenziji pažnje kao aspekta afilijativne motivacije. Manji uzorak vlasnika pasa ostvaruje značajno viši rezultat na ovom aspektu motivacije za socijalnim kontaktom. U odnosu na emocionalnu podršku, pozitivnu stimulaciju i socijalne usporedbe, pažnja je aspekt afilijativne motivacije koji ima naglašenu 
egoističnu, pa čak i narcističnu dimenziju. Ljudi koji ostvaruju više rezultate vole biti u društvu drugih ako osjećaju da ih ti drugi veličaju, da im se dive, odnosno da im poklanjaju punu pažnju. Moguće je da ovako specificirana potreba za socijalnim kontaktom proizlazi iz stabilnijih obilježja osobnosti takvih ljudi kao orijentiranih na sebe i vlastitu promociju, što bi išlo u prilog lošijem interpersonalnom funkcioniranju u bliskim odnosima utvrđenom kod manjeg uzorka vlasnika pasa u ovom istraživanju. U svakom slučaju još je jedan rezultat koji nudi zanimljive ideje budućim istraživanjima u ovom području.

\section{ZAKLJUČAK}

Uzorak vlasnika pasa do kojeg se došlo tehnikom tzv. snježne grude i tzv. samoregrutirani uzorak vlasnika pasa razlikuju se u temeljnim varijablama interpersonalnog funkcioniranja - privrženost u bliskim odnosima i usamljenost. Kvalitetnija realizacija bliskih interpersonalnih odnosa i veće životno zadovoljstvo nasuprot slabijem funkcioniranju u odnosima sa značajnim drugima i manjem životnom zadovoljstvu čine se značajnim faktorima u smislu formiranja privrženosti u odnosu s kućnim ljubimcem. Skupina vlasnika pasa koja je lošija na interpersonalnom planu, privrženija je svom ljubimcu. Njihova motivacija za socijalnim kontaktom sadržana u potrebi za pažnjom i samouzdizanjem, koje proizlazi iz te pažnje, ušućuje na moguće odrednice interpersonalnog funkcioniranja unutar ličnosti.

Proučavanje kvalitete odnosa koji se formira između čovjeka i njegova kućnog ljubimca u našoj je zemlji tematika koja tek gradi svoj put u znanosti. Strana literatura u ovom području fokusirana je na iznalaženje valjanih metodoloških rješenja prilikom mjerenja kvalitete privrženosti u odnosu vlasnik-kućni ljubimac. Funkcije privrženosti indiciraju realizaciju i kvalitetu privrženog ponašanja na razini specifičnog odnosa, što nadilazi emocionalnu bliskost koja se u velikom broju studija uzima kao isključivi indikator privrženosti. Kao temeljni doprinos istraživanja ipak se treba izdvojiti naznaka da je moguće diferencirati vlasnike pasa prema aspektima interpersonalnog funkcioniranja u bliskim odnosima, a koji, čini se, predstavljaju faktor relevantan u kontekstu formiranja privrženosti ljubimcu. Kontrola varijabli vezanih uz kvalitetu bliskih odnosa mogla bi rasvijetliti dileme vezane uz najintrigantnije rezultate istraživanja u ovom području koji se tiču pozitivnih efekata društva ljubimca na psihofizičko funkcioniranje čovjeka. Istraživanje je, sve u svemu, pružilo značajne smjernice za budući rad u ovom području.

\section{LITERATURA}

Carlisle-Frank, P. i Frank, J.M. (2006). Owners, guardians, and owner-guardians: Differing relationships with pets. Anthrozoös, 19 (3), 225-242. 
Ćubela Adorić, V. (2004). Skala socijalne i emocionalne usamljenosti. U: V. Ćubela, K. Lacković-Grgin, Z. Penezić i A. Proroković (Ur.), Zbirka psihologijskih skala i upitnika. Svezak 2, 52-62. Zadar: Sveučilište u Zadru.

Diener, E., Emmons, R.A., Larsen, R.J. i Griffin, S. (1985). The satisfaction with lifes cale. Journal of Personality Assessment, 49 (1), 71-75.

Johnson, T.P., Garrity, T.F., Stallones, L. (1992). Psychometric evaluation of the Lexington Attachment to Pets Scale (LAPS). Anthrozoös, 5 (3), 160-175.

Jugović, I. (2004). Zadovoljstvo rodnim ulogama. Diplomski rad. Filozofski fakultet, Sveučilište u Zagrebu.

Kamenov, Ž. i Jelić, M. (2003). Validacija instrumenta za mjerenje privrženosti u različitim vrstama bliskih odnosa: Modifikacija Brennanova Inventara iskustava u bliskim vezama. Suvremena psihologija, 6 (1), 73-91.

Kurdek, L.A. (2008). Pet dogs as attachment figures. Journal of Social and Personal Relationships, 25 (2), 247-266.

Kurdek, L.A. (2009). Pet dogs as attachment figures for adult owners. Journal of Family Psychology, 23 (4), 439-446.

Lacković-Grkin, K. (2002). Skala afilijativne motivacije. U: K. Lacković-Grgin, A. Proroković, V. Ćubela, Z. Penezić (Ur.) .), Zbirka psihologijskih skala i upitnika. Svezak 1, 42-45. Zadar: Sveučilište u Zadru.

Lacković-Grgin, K. (2004). Adaptirana Loyola skala generativnosti. U: V. Ćubela, K. Lacković-Grgin, Z. Penezić i A. Proroković (Ur.), Zbirka psihologijskih skala i upitnika. Svezak 2., 1-6. Zadar: Sveučilišste u Zadru.

Levačić, J. (2009). Pokušaj validacije Adaptirane Lexington skale privrženosti kućnim ljubimcima. Suvremena psihologija, 12, 391.405.

Larose, S., Guay, F. i Boivin, M. (2002). Attachment, social support, and loneliness in young adulthood: A test of two models. Personality and Social Psychology Bulletin. 28 (5), 684-693.

McAdams, D.J., De St. Aubin, E. (1992). A theory of generativity and its assessment through self-report, behavioral acts, and narrative themes in autobigraphy, Journal of Personality and Social Psychology, 62, 1003-1015.

Mikulincer, M. i Shaver, P.R. (2007). Attachment in adulthood: structure, dynamics and change. The Guilford Press. New York.

Ombla, J. (2014). Provjera teorije privrženosti na odnosu vlasnika prema kućnim ljubimcima. Doktorska disertacija. Filozofski fakultet, Sveučilište u Zagrebu.

Ombla, J. i Penezić, Z. (2010). Privrženost kućnim ljubimcima i neke karakteristike vlasnika pasa. U: I. Sorić, V. Ćubela Adorić, Lj. Gregov, Z. Penezić (Ur.), Sažeci radova/ Zadar. Usmeno priopćenje s: XVII. Dana psihologije u Zadru. Sveučilište u Zadru.

Shaver, P.R. i Mikulincer, M. (2010). New directions in attachment theory and research. Journal of Social and Personal Relationships, 27 (2), 163-172.

Shore, E.R., Riley, M.L. i Douglas, D.K. (2006). Pet owner behaviors and attachment to yard versus house dogs. Anthrozoös, 19 (4), 325-334.

Siegel, J. M. (1990). Stressful life events and use of physician services among the elderly. Journal of Personality and Social Psychology, 58, 1081-1086. 


\title{
QUALITY OF CLOSE RELATIONS IN DOG OWNERS AND ASPECTS OF ATTACHMENT TO THE PET
}

\begin{abstract}
Pet ownership does not have an explicitly defined purpose, still it seems to be a mutual affective relation. This is emphasized when it comes to dogs as pets. Dogs are the most popular pet species and people express that they form strong emotional bonds with dogs. Research shows that sometimes pets compensate the lack of human attachment bonds, while in other cases they expand the range of relations and social contacts that contribute to general life satisfaction and give support in stressful moments.

The aim of this research was to determine if two samples of dog owners differ in some aspects of quality of close interpersonal relations, considering certain aspects of attachment to their pet dogs.

Results confirm the expectations; the sample of dog owners recruited by the snow ball technique reports higher quality of close interpersonal relations as well as higher life satisfaction, while the self-recruited sample of dog owners has weaker quality of relations with significant others and they are less satisfied with their life. Furthermore, the sample of dog owners who form weaker interpersonal bonds are more attached to their pet. Their affiliative motivation is distinguished by the need for attention and following self-praise which points to possible personality factors as relevant for interpersonal functioning.
\end{abstract}

Key words: attachment, loneliness, interpersonal relations, pets 
